\title{
STUDIES ON GRANULOMA INGUINALE IV. GROWTH REQUIREMENTS OF DONOVANIA GRANULOMATIS AND ITS RELATIONSHIP TO THE NATURAL HABITAT OF THE ORGANISM*†
}

BY

\author{
JULIUS GOLDBERG
}

Department of Microbiology and Public Health, Chicago Medical School

While the postulates of Koch have never been fulfilled in granuloma inguinale, there is much presumptive evidence to indicate that Donovania granulomatis is the aetiological agent of the disease. The prototype of $D$. granulomatis was isolated originally by Anderson (1943), and since that time at least six other investigators (Beveridge, 1945; Dienst, 1948; Goldberg, Weaver, and Packer, 1953; Jennison, Helwig, and Milstone, 1947; Sheldon, Thebaut, Heyman, and Wall, 1945; Thomison, 1951) have isolated additional strains. The organism isolated in each of these cases was a Gram-negative pleomorphic rod which grew only in the presence of egg yolk material. Morphologically these organisms showed bipolar staining with Wright's stain and, when capsulated, closely resembled the Donovan bodies which are pathognomonic for the disease.

In addition to the morphological similarity between Donovania and the Donovan body, serological data indicate that patients with granuloma inguinale have antibodies directed against the Donovania. Anderson, DeMonbreun, and Goodpasture (1945) were able to show that an antigen prepared from one of their strains of Donovania reacted with sera from patients with the disease. Goldberg, Weaver, Packer, and Simpson (1953) have shown by complement-fixation tests that 136 out of 151 sera from patients with granuloma inguinale gave positive reactions with antigens prepared from strains of Donovania. Only one of 112 of their control sera gave a positive reaction. The data also indicated that the titres of the sera increased with the duration of the disease.

\footnotetext{
* Received for publication September 6, 1959.

† Supported by grant E1239, from the Institute of Allergy and Infectious Diseases, United States Public Health Service.
}

If we assume that $D$. granulomatis is the aetiological agent of granuloma inguinale, two pertinent questions must be answered:

(1) What is the normal habitat of the organism?

(2) How is it transmitted from patient to patient?

In spite of the fact that the literature contains much reference to the venereal transmission of the disease, epidemiological evidence indicates that the disease is not spread by sexual means. For example, Packer (1959) observed that in over 500 of his cases of granuloma inguinale he was able to detect the disease in only two of the marital partners.

Recent work in our laboratory has indicated that the Donovania are not so fastidious as previously reported and that the cultural conditions necessary for growth are such that these data may shed some light on the natural habitat of the organism.

\section{Methods}

In the work reported here, four strains of Donovania granulomatis were used:

(1) The Anderson strain, isolated by Dr. K. Anderson in 1943 and obtained from Dr. A. D. Dulaney, University of Tennessee College of Medicine in 1948;

(2) The Franklin strain, isolated by the author in Memphis, Tennessee, in 1948;

(3) The Allen strain, isolated by Dr. R. B. Dienst in Augusta, Georgia, and obtained from him in 1948;

(4) The Tennessee strain, isolated by Dr. J. B. Thomison in Nashville, Tennessee, and obtained from him in 1951.

These strains were inoculated into the yolk-sac of 5-day-old embryonic eggs. After 4 days' incubation at $37^{\circ} \mathrm{C}$., the yolk material was removed aseptically and inoculated in suitable amounts into in vitro egg yolk 
media previously shown to support growth of the Donovania. The Dulaney medium used is essentially 50 per cent. egg yolk in Locke's solution coagulated in the slanting position by the use of heat and then overlaid with sterile Locke's solution. The material containing viable Donovania was inoculated into the overlay.

\section{Results}

Inoculations into the in vitro medium gave contradictory results. Some growth did occur, but no consistent results were obtained. A similar situation had occurred some years previously when it was found that the diet of the hen was of great importance to the growth-promoting properties of the yolk material obtained from her eggs (Goldberg and others, 1953). Yolk material from various types of egg was substituted in the media with no better results. Finally, by a process of trial and error, it was found that the oxidation-reduction (O-R) potential of the medium was of prime importance. If Dulaney slants were prepared as usual and then overlaid with sterile fluid thioglycollate medium* instead of Locke's solution, a good growth of the Donovania would ensue, but thioglycollate medium alone or the usual infusion broths would not support continued growth of the organism. Table I shows the results obtained.

TABLE I

GROWTH OF D. GRANULOMATIS IN VARIOUS MEDIA

\begin{tabular}{c|c|c|c|c|c|c|c|c|c|c|c|c}
\hline \multicolumn{1}{c|}{ Medium } & 1 & 2 & 3 & 4 & 5 & 6 & 7 & 8 & 9 & 10 & 11 & 12 \\
\hline $\begin{array}{c}\text { Yolk + Locke's } \\
\text { Solution }\end{array}$ & \pm & \pm & \pm & - & - & - & - & - & - & - & - & - \\
\hline $\begin{array}{c}\text { Yolk + Thiogly- } \\
\text { collate Medium }\end{array}$ & 4 & 4 & 4 & 4 & 4 & 4 & 4 & 4 & 4 & 4 & 4 & 4 \\
\hline $\begin{array}{c}\text { Thioglycollate } \\
\text { Medium }\end{array}$ & 3 & 4 & \pm & 3 & 1 & \pm & - & & - & & & \\
\hline $\begin{array}{c}\text { Heart Infusion } \\
\text { Broth }\end{array}$ & \pm & - & - & - & & & & & & & & \\
\hline$-=$ No growth. & \pm to 4 & $=$ Degrees of growth.
\end{tabular}

It was inferred from the results obtained that two

* Fluid thioglycollate medium was obtained from Baltimore Biological Laboratories, Baltimore, Maryland:

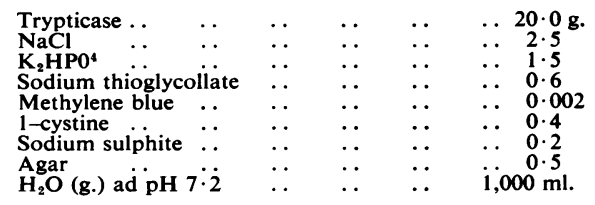

conditions were necessary for the successful propagation of Donovania:

(1) A factor or factors present in egg yolk,

(2) A proper oxidation-reduction (O-R) potential.

The growth of the organism in egg-thioglycollate medium suggested that these organisms were either anaerobic or micro-aerophilic. Under suitable conditions an egg yolk medium may furnish both conditions.

After the importance of the correct $\mathrm{O}-\mathrm{R}$ potential had been determined, an attempt was made to find a substance or substances which would be able to replace the factor or factors normally present in egg yolk. Numerous substances were tested but only two were found to supply the factor necessary. These substances were lactalbumin hydrolysate (an enzymatic digest of albumin supplied by Nutritional Biochemicals Corporation) and Phytone (an enzymatic digest of soya meal produced by Baltimore Biological Laboratories). When these substances were incorporated into a synthetic medium a good growth of the Donovania resulted. The medium had the following composition:

\begin{tabular}{|c|c|c|}
\hline olsate & ytone & \\
\hline Sodium chloride & & \\
\hline phosphate & & \\
\hline thioglycollate & & \\
\hline ne & & \\
\hline
\end{tabular}

The ingredients were added to the $1,000 \mathrm{ml}$. of water and dissolved with heat. The medium was allowed to cool and adjusted to $\mathrm{pH} 7 \cdot 2$. The medium was placed in screw-capped tubes in volumes of 20-22 ml. and sterilization was accomplished at $21^{\circ} \mathrm{C}$. for $15 \mathrm{~min}$. After sterilization was accomplished the caps were tightened to insure the maintenance of reduced conditions in the medium.

Interestingly enough, chemically digested peptone products did not support growth of the organism.

For the past year, with over one hundred transfers, the four strains of Donovania granulomatis have been successfully cultured in the above medium.

The following characteristics of lactalbumin hydrolysate have led us to believe that the active principle is probably of a polypeptide nature:

(a) Autoclaving does not destroy the factor.

(b) Heat and 10 per cent. trichloro-acetic acid do not produce a precipitate.

(c) The factor is not dialysable through ordinary dialysing membranes.

(d) Treatment with strong acids and alkalis without heat destroys the factor. 
(e) Strong ninhydrin and biuret reactions were obtained.

Since the possibility of contamination is ever present while working with a biological material such as egg yolk, this possibility had to be taken into account. Fortunately, the problem of possible contamination could be resolved with some success because antigens and antisera were available which had been prepared 10 to 12 years ago and preserved in the frozen state. Previous work had shown that these antigens reacted with 136 out of 151 sera from granuloma inguinale patients in whom Donovan bodies had been demonstrated. Antigen and $D$. granulomatis rabbit antisera produced from the strains grown in lactalbumin hydrolysate medium were also available.

The serological data obtained are outlined in Table II. It is obvious that the strains now under cultivation contain many of the antigens found in the strains cultured 10 to 12 years ago. These findings suggest that the organisms under cultivation are not contaminants.

TABLE II

COMPLEMENT-FIXATION REACTIONS OF VARIOUS STRAINS OF DONOVANIA GRANULOMATIS WITH VARIOUS D. GRANULOMATIS ANTISERA

\begin{tabular}{|c|c|c|c|c|c|c|}
\hline Antigen & $\begin{array}{l}\text { Frank- } \\
\text { lin } \\
(1949)\end{array}$ & \begin{tabular}{|l} 
Allen \\
$(1950)$
\end{tabular} & $\begin{array}{l}\text { Ander- } \\
\text { son } \\
(1949)\end{array}$ & $\begin{array}{l}\text { Frank- } \\
\operatorname{lin} \\
(1958)\end{array}$ & $\begin{array}{l}\text { Allen } \\
\text { (1958) }\end{array}$ & $\begin{array}{l}\text { Ander } \\
\text { son } \\
(1958)\end{array}$ \\
\hline $\begin{array}{l}\text { Anderson (1948) } \\
\text { Anderson (1958) } \\
\text { Franklin (1948) }\end{array}$ & \multirow{2}{*}{$\begin{array}{c}80+ \\
40 \\
\text { Not } \\
\text { done } \\
40\end{array}$} & \multirow{4}{*}{$\begin{array}{c}80+ \\
80+ \\
\text { Nega- } \\
\text { tive } \\
\text { Nega- } \\
\text { tive } \\
\text { Nega- } \\
\text { tive }\end{array}$} & \multirow{4}{*}{$\begin{array}{c}80+ \\
80+ \\
\text { Not } \\
\text { done } \\
\text { Not } \\
\text { done } \\
\text { Not } \\
\text { done }\end{array}$} & \multirow{4}{*}{$\begin{array}{l}40+ \\
80+ \\
20 \\
20 \\
\text { Not } \\
\text { done }\end{array}$} & $\begin{array}{r}80+ \\
640\end{array}$ & $\begin{array}{c}80+ \\
640\end{array}$ \\
\hline Franklin (1958) & & & & & 40 & 80 \\
\hline Allen (1958) & & & & & 320 & 1,280 \\
\hline Allen (19J0) .. & & & & & 640 & 640 \\
\hline
\end{tabular}

* Reciprocal of highest dilution of serum showing 3-4+ inhibition of haemolysis.

$+=4=$ in highest dilution tested.

The antigens and antisera were prepared during the year noted in the top row. The antigen prepared in 1948 was shown to react with 95 per cent. of sera from patients with granuloma inguinale.

\section{Discussion}

The data presented here indicate that the two factors necessary for growth of the Donovania are:

(1) A peptide-like substance,

(2) anaerobic or micro-aerophilic cultural conditions.

The intestinal tract is the one area of the body which we feel would easily furnish both conditions. In addition, there is serological evidence that the Donovania may share antigens with some members of the Enterobacteriaceae. Rake (1948) reported that, of thirty sera from patients with granuloma inguinale, 25 were positive with $D$. granulomatis antigen, 66 per cent. with Klebsiella pneumoniae antigen, 89 per cent. with Klebsiella rhinoscleromatis antigen, 45 per cent. with Escherichiae coli antigen, and 36 per cent. with Aeruginosa aerogenes antigen.

Packer and Goldberg (1950) reported similar results using anti- $D$. granulomatis rabbit serum, and were able to show complement fixation with antigens prepared from strains of Klebsiella, Aerobacter, and Escherischiae, and from the abovementioned antiserum.

The postulated faecal habitat of Donovania is not new, for DeMonbreun and Goodpasture (1931), as well as Rake (1948), have suggested it, although the suggestion was based on different reasoning in each case.

We feel that the data presented here, together with those indicating a serological relationship between the Donovania and some members of the tribe Enterobacteriaceae, strengthen the postulated faecal origin of Donovania granulomatis. Further investigation in this direction appears to be indicated.

\section{Summary}

Donovania granulomatis has hitherto been reported to grow only on material containing egg yolk material. Evidence is presented to indicate that two factors are necessary for growth:

(1) A low oxidation-reduction potential which can be satisfied by the use of a thioglycollate medium;

(2) A factor or factors found in egg for which may be substituted the enzymatic digests of bovine albumin or soya meal.

Acid hydrolysis of these materials destroys this factor. Presumptive evidence is presented to indicate that this factor is probably a peptide. These findings along with the previously published serological relationships between $D$. granulomatis and members of the Enterobacteriaceae, strengthen the idea of a faecal habitat of $D$. granulomatis.

\section{REFERENCES}

Anderson, K. (1943). Science, 97, 560.

- DeMonbreun, W. A., and Goodpasture, E. W. (1945). J. Exp. Med., 81, 25.

Beveridge, W. I. B. (1945). J. Immunol., 53, 215.

DeMonbreun, W. A., and Goodpasture, E. W. (1931). Amer. J. trop. Med., 11, 311.

Dienst, R. B. (1948). In "Recent Advances in the Study of Venereal Diseases: A Symposium", p. 266. Venereal Diseases Education Institute, Raleigh, N.C.

Goldberg, J., Weaver, R. H., and Packer, H. (1953). Amer. J. Syph., 37,60 .

Jennison, D. B., Helwig, E. B., and Milstone, J. H. (1947). Arch. Derm. Syph. (Chicago), 55, 342.

Packer, N. (1959). Personal communication.

- and Goldberg, J. (1950). Amer. J. trop. Med., 30, 387.

Rake, G. (1948). Amer. J. Syph., 32, 150.

Sheldon, W. H., Thebaut B. R., Heyman, A., and Wall, M. J. (1945). Amer. J. med. Sci., 210, 237.

Thomison, J. B. (1951). Proc. Soc. exp. Biol. (N.Y.), 77, 557. 